\title{
Adaptation of a Cervical Cancer Education Program for African Americans in the Faith-Based Community, Atlanta, Georgia, 2012
}

Venice Haynes, MSPH; Cam Escoffery, PhD, MPH, CHES; Corinthia Wilkerson; Rashida Bell; Lisa Flowers, MD

Suggested citation for this article: Haynes V, Escoffery C, Wilkerson C, Bell R, Flowers L. Adaptation of a Cervical Cancer Education Program for African Americans in the Faith-Based Community, Atlanta, Georgia, 2012. Prev Chronic Dis 2014;11:130271. DOI: http://dx.doi.org/10.5888/pcd11.130271 연.

PEER REVIEWED

\section{Abstract}

\section{Background}

From 1999 through 2009, African American women in the United States had the second highest incidence rates of cervical cancer and were more likely to die from cervical cancer than women of other races. Con Amor Aprendemos (CAA) is an intervention created to educate the Latino community to reduce their risk for cervical cancer and diseases related to human papilloma virus (HPV). CAA was adapted to With Love We Learn (WLWL) to prevent cervical cancer and HPV in African American communities.

\section{Community Context}

Health ministries of 2 churches in the Atlanta area partnered with the Spirit Foundation Inc to adapt CAA to WLWL by tailoring the curriculum to the African American faith-based community.

\section{Methods}

The National Cancer Institute's Research to Reality (R2R) mentorship program pair collaborated with program staff on an adaptation summary form, a tool to document and assist with adapting the program curriculum with fidelity. Trainers, faith leaders, and participants adapted the program in 4 phases: 1) review of the CAA curriculum, 2) a focus group discussion to determine changes for the WLWL curriculum, 3) train-the-trainer sessions on program delivery, and 4) a pilot intervention and follow-up focus group to evaluate the new curriculum.

\section{Outcomes}

The CAA/WLWL curriculum was adapted and piloted in a faith-based setting. Adaptations to the CAA program included pictures, games, statistics on cervical cancer, dialogues, and delivery of curriculum.

\section{Interpretation}

Community engagement in the adaptation of WLWL through various methods was critical to tailoring an evidencebased program to a new population and setting.

\section{Background}

An estimated 12,340 cases of invasive cervical cancer are expected to be diagnosed and 4,030 deaths from cervical cancer are expected for 2013 (1). Cervical cancer is the second most common cancer among women worldwide, and minorities experience disparities in cervical cancer incidence and mortality rates. From 1999 through 2009, African American women in the United States had the second highest incidence rates of cervical cancer, yet they were more likely to die from cervical cancer than women of other races (2).

Many intervention strategies have been studied to increase cervical cancer screening. The Guide to Community Preventive Services recommends client reminders, small media (eg, printed materials), one-on-one education, 
provider assessment and feedback, and provider reminders as strategies to increase cervical cancer screening (3). However, only 3 of 8 evidence-based interventions (EBIs) that focused on African American women were found on the National Cancer Institute's Research-Tested Intervention Programs website (4). Therefore, because of limitations in evidence-based options, community organizations may adapt EBIs for a new community or audience. Adaptation is defined as the degree to which an EBI is changed or modified during adoption and implementation to suit the needs of the setting or to improve the fit to local conditions (5). Several models exist that provide considerations and processes for program adaptation and implementation (6-8). In making program adaptations, it is important to address cultural mismatches and follow processes to ensure program changes fit the local populations or conditions (9).

In response to the high prevalence of cervical cancer and human papilloma virus (HPV) among Latino women, the Spirit Foundation Inc, in partnership with the American Cancer Society, South Atlantic Division, created the Con Amor Aprendemos (CAA) program for Latino couples to increase knowledge about risk and behaviors leading to cervical cancer and HPV-related diseases. This 7-week intervention is implemented by trained promotoras, or community health workers, in faith-based and community organizations. Sessions last an average of 2 hours, and each session follows a specified curriculum covering topics on anatomy, sexually transmitted infections (STIs), cervical cancer and HPV, dialogues, role playing, presentation of skits to community or church members, and education about the HPV vaccine. An extensive 2-day train-the-trainer course is a vital component of the CAA program to train a team of community members in health ministries on how to deliver the curriculum to the faith-based community. Couples are targeted to participate in the program in efforts to reduce the anxiety of the male-female partner dialogue regarding HPV and risks associated with contracting cervical cancer. The program uses innovative tools, such as a "ring of knowledge" - where program participants collect small notecards with information throughout the course of the program - games to build awareness about STIs, anatomy labeling, and a "parking lot" for participants to ask personal questions anonymously.

CAA has been implemented in Latino communities in Georgia, Nicaragua, El Salvador, and Bolivia. This intervention has been piloted in El Salvador with preliminary results demonstrating increased knowledge about HPV and Cervical Cancer (10). This article documents the process of adapting CAA for the African American community and highlights the data collection methods, adaptation of program information, and the roles of health ministry leaders to make suggestions about program modifications for a new population. The adapted program is called With Love We Learn (WLWL).

\section{Community Context}

After successful implementation in multiple Latino communities, the Spirit Foundation Inc. considered it essential to replicate the program in the African American community in light of the high incidence of cervical cancer among African American women. Without appropriate education reinforcing the importance of screening and follow-up, the rates of cervical cancer will continue to rise among African American women. As it was in the Latino community, a faith-based setting was chosen for adaptation of CAA in the African American community because of the strong historical ties the African American community has with the church. Faith-based organizations have become one of the most common vehicles for the dissemination of prevention efforts and addressing health concerns for that population $(11,12)$.

In October 2011, the Spirit Foundation partnered with 2 churches in the metro Atlanta area that would adopt WLWL in their health ministries. These churches have predominantly African American populations with congregations of 4,000 members or more (Table 1). Health ministry leaders from these churches were invited to participate in the community assessment and adaptation discussions.

\section{Methods}

In 2011, the National Cancer Institute piloted the Research to Reality (R2R) mentorship program as a capacitybuilding initiative for public health practitioners to gain hands-on experience in evidence-based programs and decision -making practices. Mentees were paired with seasoned cancer control practitioners and worked on a year-long cancer control and prevention project to learn and apply new skills in evidence-based public health practices. The project for the Georgia R2R pair focused on the adaptation of CAA to WLWL. Orientation meetings were held with program developers and staff members to learn the details of the program, and worked for several months to gather information that would inform the key phases at which data would be gathered in the adaptation process. The adaptation summary form was the primary tool used among project staff to document the changes at each phase (Figure 1). The program was adapted in 4 phases: 1) review of the CAA curriculum, 2) a focus group discussion to determine changes for the WLWL curriculum, 3) train-the-trainer sessions on program delivery, and 4) a pilot intervention and follow-up focus group to evaluate the new curriculum. 


\begin{tabular}{|c|c|c|c|c|c|}
\hline $\begin{array}{l}\text { PROGRAM } \\
\text { COMPONENT }\end{array}$ & $\begin{array}{l}\text { ADAPTATION } \\
\text { CONSIDERATIONS }\end{array}$ & $\begin{array}{l}\text { ACTUALLY } \\
\text { ADAPTED? } \\
\text { (Y/N) }\end{array}$ & REASON FOR ADAPTATION & $\begin{array}{l}\text { TYPE OF } \\
\text { ADAPTATION }\end{array}$ & MANUAL REVISION \\
\hline \multicolumn{6}{|c|}{$\begin{array}{l}\text { Session 3: Cervical Cancer And The } \\
\text { Human Papillomavirus Getting To The Truth }\end{array}$} \\
\hline $\begin{array}{c}\text { Manual } \\
\text { Review/Fecodback }\end{array}$ & $\begin{array}{l}\text { Needs more relevant } \\
\text { games }\end{array}$ & $\begin{array}{l}\text { g Yes } \\
\text { a No }\end{array}$ & $\begin{array}{l}\text { Some of the games are not sutable for the } \\
\text { participants. }\end{array}$ & $\begin{array}{l}\text { Groen Light } \\
\text { O Yellowlight } \\
\text { O Red Light }\end{array}$ & $\begin{array}{l}\text { With Love We Leatn Myth Buster was created } \\
\text { to give more variety. }\end{array}$ \\
\hline $\begin{array}{c}\text { Manual } \\
\text { Review/Feedback }\end{array}$ & $\begin{array}{l}\text { Update the stabstics for } \\
\text { women infected wth } \\
\text { Cenvical Cancer }(p g .76)\end{array}$ & $\begin{array}{l}\text { a Yes } \\
\text { a No }\end{array}$ & The statistics are of Hispaniellatina Women. & $\begin{array}{l}0 \text { Groen Light } \\
\text { g Yellow Light } \\
\square \text { Red Light }\end{array}$ & $\begin{array}{l}\text { Satisties were updated with relevance to } \\
\text { African Americans. }\end{array}$ \\
\hline $\begin{array}{l}\text { Focus Group } \\
\text { Feedback }\end{array}$ & $\begin{array}{l}\text { The relay game should } \\
\text { have a modfication. }\end{array}$ & $\begin{array}{l}\text { a Yes } \\
\text { a No }\end{array}$ & $\begin{array}{l}\text { All participants may not physically be ablo to run } \\
\text { to the board for the relay game so other fun and } \\
\text { interactive games should be thought of to play for } \\
\text { backup. The older age group ( } 50 \text {-65) may not be } \\
\text { able to play the games also. A disclaimer should } \\
\text { be used tor the beginning. }\end{array}$ & $\begin{array}{l}\text { a Groon Light } \\
\text { G Yellow Light } \\
\square \text { Red Light }\end{array}$ & $\begin{array}{l}\text { An alternative game was added that would } \\
\text { allow participants to either fun to the board or } \\
\text { have one person wite their answers. }\end{array}$ \\
\hline $\begin{array}{l}\text { Train the Trainer } \\
\text { Feedback }\end{array}$ & $\begin{array}{l}\text { ENGO should be kept } \\
\text { as an alternative. }\end{array}$ & $\begin{array}{l}\text { Yos } \\
\text { a No }\end{array}$ & $\begin{array}{l}\text { The participants felt that eINGO should be kept as } \\
\text { an option. }\end{array}$ & $\begin{array}{l}\text { Groon Light } \\
\text { g Yellow Light } \\
\square \text { Red Light }\end{array}$ & $\begin{array}{l}\text { EINGO was added as an aliernative to the } \\
\text { With Love We Learn Myths and Truth Buster. }\end{array}$ \\
\hline $\begin{array}{l}\text { Train the Trainer } \\
\text { Feedback }\end{array}$ & $\begin{array}{l}\text { Getting a follow up exam } \\
\text { to an abnormal Pap test } \\
\text { should be included. }\end{array}$ & $\begin{array}{l}\text { a Yes } \\
\text { a No }\end{array}$ & $\begin{array}{l}\text { The participants felt that getting a follow up exam } \\
\text { to an abnormal Pap test should be included to } \\
\text { instill this into the participants. }\end{array}$ & $\begin{array}{l}\text { Groon Light } \\
\text { g Yellow Light } \\
\square \text { Red Light }\end{array}$ & $\begin{array}{l}\text { Women in our community are dying because } \\
\text { they are not getting a Pap test andlor not } \\
\text { following up with an abnormal test }\end{array}$ \\
\hline $\begin{array}{l}\text { Train the Trainer } \\
\text { Fcedback }\end{array}$ & $\begin{array}{l}\text { The numbers for the } \\
\text { BiNGO game aternative } \\
\text { should be included on } \\
\text { the Myths and Truth } \\
\text { Game. }\end{array}$ & $\begin{array}{l}\text { Q Yos } \\
\text { a No }\end{array}$ & $\begin{array}{l}\text { The participants felt that the numbers should be } \\
\text { added onto the game so there would be no } \\
\text { contusion for BINGO. }\end{array}$ & $\begin{array}{l}\text { a Groen Light } \\
\text { a Yellowlight } \\
\text { a Red Light }\end{array}$ & $\begin{array}{l}\text { The myths and truths were numbered for the } \\
\text { ENGO alternative. }\end{array}$ \\
\hline Implementation & $\begin{array}{l}\text { Myth Eusters game } \\
\text { instruetons need to be } \\
\text { clanfied. }\end{array}$ & $\begin{array}{l}\text { Q Yos } \\
\text { a No }\end{array}$ & $\begin{array}{l}\text { - Teams were unclear f they passod a question to } \\
\text { the other team if they should choose another } \\
\text { question to answer or lose theis turn. } \\
\text { - Time frame for teams to reply to a question was } \\
\text { an issue. } \\
\text {-Also, The questions need to be turned over so } \\
\text { when teams choose a question, they wont read } \\
\text { the questions belore choosing. }\end{array}$ & $\begin{array}{l}\text { a Green Light } \\
\text { O Yellow Light } \\
\text { O Red Light }\end{array}$ & $\begin{array}{l}\text { Rules were modried in the Myth Busters game } \\
\text { to reflect the necessary changes: } \\
\text { - Teams that choose to puss their question to } \\
\text { the other team will tessume play after the other } \\
\text { team has answered the passed question } \\
\text { OR . teams will be timed to make team } \\
\text { collaboration fair } \\
\text { Envelopes containing questions will be turned } \\
\text { crer so each question remains anonymous. }\end{array}$ \\
\hline
\end{tabular}

Figure 1. Example of Summary Form Used During Adaptation of Con Amor Aprendemos to With Love We Learn Programs to Educate Communities About Cervical Cancer and HPV-Related Diseases, Atlanta, Georgia, 2012. [A text description of this figure is also available.]

Six health ministry leaders from the 2 partner churches reviewed the CAA program manual for general understanding of the overall curriculum. Reviews were conducted over a 2-week period, and leaders were provided with a deadline by the program developers to provide their initial feedback. Detailed notes were written throughout the manual on specific areas suggested for revision for the African American audience.

Following the manual review, 6 health ministry leaders met at one of the partner churches for a 2-hour focus group. During the focus group, leaders and program developers discussed the detailed components of the curriculum and explained how each session was to be conducted. Participants talked through the notes written throughout the manual on sections that needed revisions. A group of stakeholders from academia, government, and community collaborated on developing the focus group guide to gather detailed information about key changes to the curriculum. There were specific inquiries were made about changes to the core content and pedagogical and implementation components (13). The guide had 4 major sections that addressed the overall program and delivery, program incentives, program materials, and technical assistance in delivering the program (Appendix A). The focus group discussion was audio taped and transcribed verbatim. NVivo 10 software (QSR International, Burlington, Massachusetts) was used for data storage, retrieval, and analysis. A content analysis was performed to identify the range of responses and major themes related to revisions to the WLWL manual (14) (Table 2). A summary of the manual changes by session was also recorded on the adaptation summary form (Figure 1.)

After incorporation of the recommended changes, the WLWL manual was revised and a 2-day training workshop was conducted to train the 6 health ministry leaders on the revised curriculum. The objective of the train-the-trainer program for CAA/WLWL is to establish community educators who are motivated to address the community with accurate knowledge of HPV and cervical cancer. The training sessions were conducted on location to provide a familiar environment for the trainers. Refresher sessions were provided closer to program implementation to ensure that trainers remained comfortable teaching information accurately and did not deviate from the set topics of the curriculum. 
The first pilot of WLWL in the churches began in May 2013 with 15 (13 female and 2 male) participants. Participants were recruited through church announcements, fliers, and word of mouth from the health ministry leaders. Not all of the participants were couples, however all 15 participants completed the adapted program in June 2013. On

completion, participants and trainers were invited to participate in a focus group discussion to gather their feedback. Participants were asked their opinions about the marketing of the program to their congregation, their comfort level with questionnaires that asked about sensitive and personal information, receptivity to the session topics and components, and their recommendations for recruiting participants in future programs. Data gathered from the pilot group of WLWL participants served as the final data collection point to include on the adaptation summary form for the last manual revisions.

The overall program curriculum and the focus group guide was submitted under the Emory University Social and Behavioral Institutional Review Board and received exemption from full review. Trainers were compensated for their time for the manual review, focus group discussion, and train-the-trainer session. and participants in the pilot program were compensated for their feedback during the focus group. The R2R mentorship pair, program developers, and WLWL project staff followed adaptation guidance from the literature (15) to summarize all of the suggestions provided for tailoring, ensuring that the recommended changes did not affect the fidelity to the original core elements or required elements of the program (16).

\section{Outcomes}

Overall, the program was well received by church leaders, trainers, and participants of the pilot intervention. Each phase of the adaptation process included valuable recommendations for the WLWL curriculum (Figure 2). Suggestions for content tailoring included changes to the cover, games related to session topics, pictures to reflect African Americans, and more effective dialogue to deliver the content of the sessions to an African American population. The modification of relevant health statistics addressing screening rates and cervical cancer mortality for African American women was also critical to effectively communicate risk data to participants. Other modifications included recommendations for stratifying the program by age groups to promote easier conversations with peers closer in age. The frequency of the sessions was condensed to twice a week for 3 weeks to retain members' participation throughout the program (Table 3). Core elements of the program, including the session topics and the use of games, pictures, posters, and dialogues for learning the material, were not changed. Although these materials were welcomed and reported to be helpful in learning, suggestions were given to make them relevant to both younger and older African American audiences in the community. The program developer, a gynecologist, and other program staff reviewed the comments and modified the pilot WLWL curriculum.

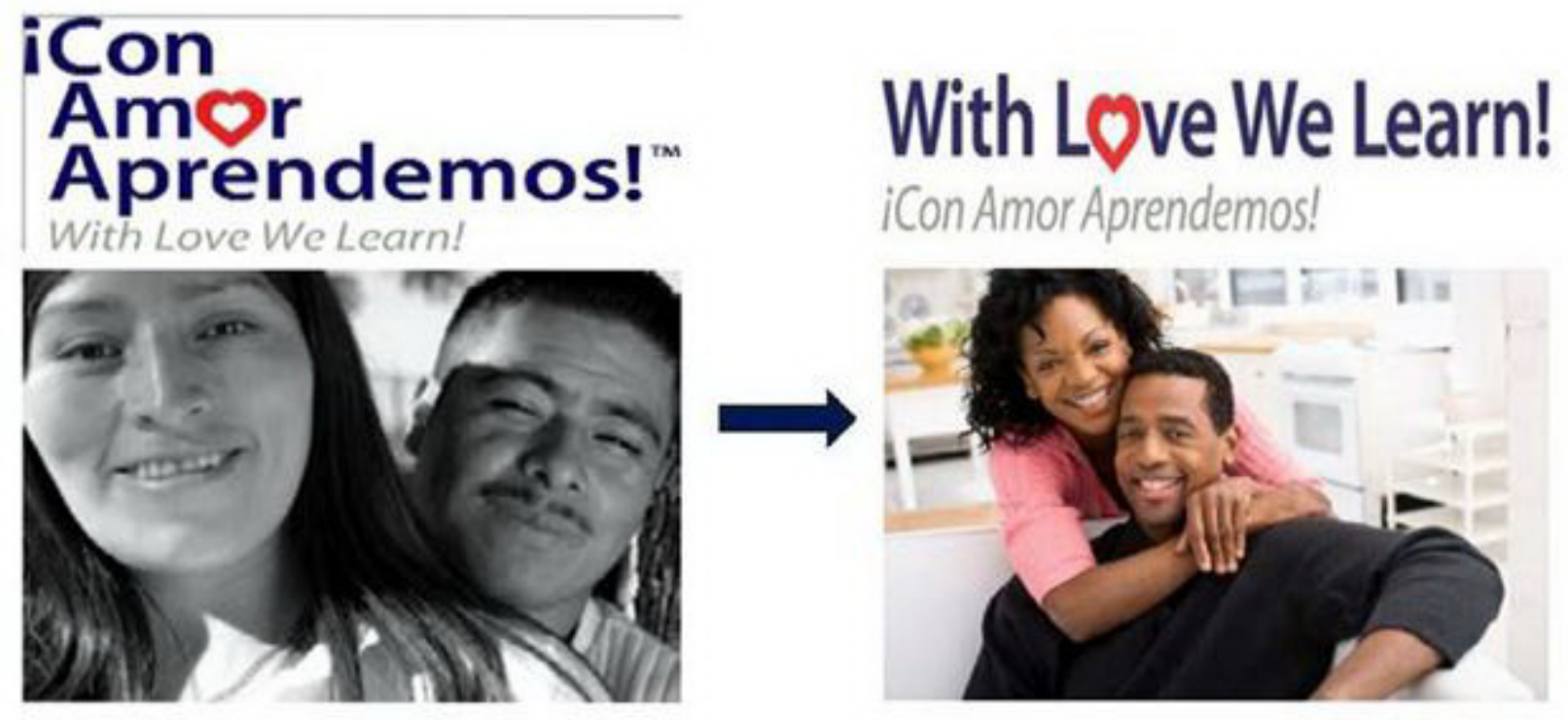

Figure 2. Changes to Con Amor Aprendemos for the Cover of With Love We Learn Manual, Atlanta, Georgia, 2012. [A text description of this figure is also available.]

\section{Interpretation}

Program adaptation is an important process in the translation of evidence-based programs into practice. A systematic process for adaptation is necessary to learn what potential changes can be made to a program to ensure its suitability 
for another population and also balance fidelity to the original program. Community engagement is equally important for this adaptation process to garner insights from key constituents and understand contextual issues in matching interventions to particular communities. Castro and colleagues summarize key processes in program adaptation including assessing your audience, selecting an evidence-based approach, preparing for adaptation with focus groups or topical expert review, adapting the program, testing adaptation materials, and refining adaptation $(15,17)$. We followed the guidance for adaptation preparation with multiple data collection methods to learn about the target audience (needs assessment) and assist in making decisions on what program components to change or refine.

One of the most important considerations for adapting community programs is to understand both the intervention and the components required for program fidelity to remain uncompromised. Additionally, it is equally important to take the time to foster the right partnerships with faith-based institutions and involve the right stakeholders' perspectives to ensure the programs' success. Substantial organization and investment of time are needed to collect data at multiple points. Working closely with the program developers and staff on organizing the data collection throughout the adaptation phases was extremely helpful in keeping the project on track and without losing the fidelity of the original program. Having a resource like the adaptation summary form referenced throughout this case study, is highly recommended to keep records of the changes in a multiphase process.

The data collection and subsequent adaptation of the CAA program involved a variety of stakeholders from program developers to key members of the faith-based organizations to identify areas of original program mismatches (eg, race, community context) to the African American population. The multiple types of data collection generated many recommendations for program changes to increase the fit of the cervical cancer prevention program to African American church members. Many of our program changes fit into the area of context modification (eg, setting, population) and content modification (eg, tailoring, substituting elements) found in a recent review of adaptation of evidence-based interventions (18).

We involved the program developers in this adaptation process in order to speak to the dynamics of the program, the role of the faith-based organization that would be implementing it, and to make informed decisions on what to change in the program. This strategy has been suggested as a way to ensure that the modifications are justifiable and that changes to the content, duration, or delivery style of the program will not diminish the program's effectiveness $(19,20)$. Linking program developers to community organizations that are adopting evidence-based programs can increase translations of EBIs in that developers can address issues related to program implementation and adaptation (21). Decisions were made by the developers to change certain CAA content and implementation recommendations if they were not deemed to be "red light" adaptations (eg, theory change, dose, elimination of core elements) that would potentially jeopardize program fidelity (13).

Dissemination of evidence-based practices is increasing in the community. Many community organizations are attempting to adapt packaged programs for their own populations and settings. This project has illustrated a method for sequential data collection to inform the adaptation process. Future research should further explore how community -based participatory processes with key community members and organizations can inform program adaptations of evidence-based interventions and testing of adapted programs in communities for effectiveness.

\section{Acknowledgments}

This project was funded in part by Centers for Disease Control and Prevention (grant no. 5U58DPooo984), Morehouse School of Medicine Prevention Research Center Cancer Unit, the Emory Cancer Prevention and Control Research Network in the Emory Prevention Research Centers Program (no. U48DPo01909), and the Spirit Foundation Inc, Lithonia, Georgia. We also thank Olga Lucia Jimenez with the South Atlantic Division of the American Cancer Society, Winifred Thompson with Emory University Rollins School of Public Health, and the health ministry trainers of the partner churches.

\section{Author Information}

Corresponding Author: Venice E. Haynes, MSPH, Morehouse School of Medicine, 720 Westview Drive SW Atlanta, GA 30310. Telephone: 404-756-8832. E-mail: vhaynes@msm.edu.

Author Affiliations: Cam Escoffery, Emory University, Rollins School of Public Health, Atlanta, Georgia; Corinthia Wilkerson, Spelman College, Atlanta, Georgia; Rashida Bell, Spirit Foundation Inc, Lithonia, Georgia; Lisa Flowers, Emory University School of Medicine, Atlanta, Georgia.

\section{References}

1. Cancer facts and figures, 2013. Atlanta (GA): American Cancer Society; 2013. 
2. Centers for Disease Control and Prevention. Cervical cancer death rates by race/ethnicity. US Mortality Files. http://www.cdc.gov/cancer/cervical/statistics/race.htm. Accessed May 24, 2013.

3. Sabatino SA, Lawrence B, Elder R, Mercer SL, Wilson KM, DeVinney B, et al. ; Community Preventive Services Task Force. Effectiveness of interventions to increase screening for breast, cervical, and colorectal cancers: nine updated systematic reviews for the Guide to Community Preventive Services. Am J Prev Med 2012;43(1):97-118. CrossRef 圈 PubMed 圈

4. National Cancer Institute. Research-tested intervention programs (RTIPs). http://rtips.cancer.gov/rtips/. Accessed May 24, 2013.

5. Rabin BA, Brownson RC, Haire-Joshu D, Kreuter MW, Weaver NL. A glossary for dissemination and implementation research in health. J Public Health Manag Pract 2008;14(2):117-23. CrossRef 圈 PubMed 圈

6. Kumpfer KL, Pinyuchon M, Melo AT, Whiteside HO. Cultural adaptation process for international dissemination of the Strengthening Families Program. Eval Health Prof 2008;31(2):226-39. CrossRef 圈 PubMed :

7. McKleroy VS, Galbraith JS, Cummings B, Jones P, Harshbarger C, Collins C, et al. Adapting evidence-based behavioral interventions for new settings and target populations. AIDS Educ Prev 2006;18(Suppl A):59-73. CrossRef 圈 PubMed 圈

8. Wingood GM, DiClemente RJ. The ADAPT-ITT Model: a novel method of adapting evidence-based HIV interventions. J Acquir Immune Defic Syndr 2008;47(Suppl 1):S40-6. CrossRef 圈 PubMed 圈

9. Castro FG, Barrera M, Martinez CR. The cultural adaptation of prevention interventions: Resolving tensions between fidelity and fit. Prev Sci 2004;5(1):41-5. CrossRef 圈 PubMed 圈

10. Flowers LC, Kirsch LJ, Escoffery C. An evaluation of the "Con Amor Aprendemos" cervical cancer education intervention for Latino couples in El Salvador [abstract]. In: Proceedings of the Sixth AACR Conference on The Science of Cancer Health Disparities in Racial/Ethnic Minorities and the Medically Underserved; 2013 Dec 6-9; Atlanta, Georgia. Philadelphia (PA): AACR; 2013. p. 130-1. Abstract no. A52.

11. Braithwaite RL, Taylor SE. Health issues in the black community. Second edition. San Francisco (CA): Jossey Bass; 2001.

12. Baskin ML, Resnicow K, Campbell MK. Conducting health interventions in black churches: a model for building effective partnerships. Ethn Dis 2001;11(4):823-33. PubMed 圈

13. Firpo-Triplett R, Fuller TR. General adaptation guidance: a guide to adapting evidence-based sexual health curricla. ETR Associates; 2012.

http://recapp.etr.org/recapp/documents/programs/GeneralAdaptationGuidanceFINAL.pdf. Accessed May 23, 2013.

14. Miles M, Huberman A. Qualitative data analysis: an expanded sourcebook. Second edition. Thousand Oaks (CA): Sage Publications; 1994.

15. Castro FG, Barrera M Jr, Holleran Steiker LK. Issues and challenges in the design of culturally adapted evidencebased interventions. Annu Rev Clin Psychol 2010;6:213-39. CrossRef 圈 PubMed 圈

16. Eke AN, Neumann MS, Wilkes AL, Jones PL. Preparing effective behavioral interventions to be used by prevention providers: the role of researchers during HIV Prevention Research Trials. AIDS Educ Prev 2006;18(4 Suppl A):44-58. CrossRef 国 PubMed 圈

17. Barrera M Jr, Castro FG. A heuristic framework for the cultural adaptation of interventions. Clin Psychol Sci Pract 2006;13(4):311-6. CrossRef 圈

18. Stirman SW, Miller CJ, Toder K, Calloway A. Development of a framework and coding system for modifications and adaptations of evidence-based interventions. Implement Sci 2013;8:65. CrossRef 国 PubMed 圈

19. O'Connor C, Small SA, Cooney SM. Program fidelity and adaptation: meeting local needs without compromising program effectiveness: what works, Wisconsin Research to Practice Series, 4. Madison (WI): University of Wisconsin-Madison/Extension; 2007.

20. Chen EK, Reid MC, Parker SJ, Pillemer K. Tailoring evidence-based interventions for new populations: a method for program adaptation through community engagement. Eval Health Prof 2013;36(1):73-92. CrossRef 圈 PubMed 国

21. Rohrbach LA, Grana R, Sussman S, Valente TW. Type II translation: transporting prevention interventions from research to real-world settings. Eval Health Prof 2006;29(3):302-33. CrossRef 圈 PubMed 圈

\section{Tables}


Table 1. Profile of Churches Participating in Adaptation of Con Amor Aprendemos to With Love We Learn, Atlanta, Georgia, 2012

\begin{tabular}{|l|l|l|}
\hline Characteristic & \multicolumn{1}{|c|}{ Church 1: Baptist } & Church 2: Nondenominational \\
\hline Primary race/ethnicity & African American & Predominantly African American \\
\hline Location/neighborhood & Decatur, Georgia & Decatur, Georgia \\
\hline Size of congregation & $4,000+$ & $7,000+$ \\
\hline Health ministry present? & Yes & Yes \\
\hline Participants in train-the-trainer workshop & 4 & 2 \\
\hline
\end{tabular}

Table 2. Focus Group Comments from Trainers Related to Adapting Con Amor Aprendemos to With Love We Learn, Atlanta, Georgia, 2012

\begin{tabular}{|c|c|}
\hline Topic & Trainer Comment \\
\hline \multicolumn{2}{|c|}{ Overall Program and Delivery } \\
\hline \multirow[t]{2}{*}{$\begin{array}{l}\text { Age categories } \\
\text { appropriate }\end{array}$} & $\begin{array}{l}\text { ". . you may want 3. My guess, and I just suggest } 21 \text { to } 29,30 \text { to } 44,45 \text { to } 60 \text { or } 45 \text { and } \\
\text { above." }\end{array}$ \\
\hline & $\begin{array}{l}\text { "I would probably do it like he did, like you have the younger adults } 21 \text { to } 29 \text {, then say your } \\
\text { middle-aged group from } 30 \text { to } 44 \text {, then maybe } 45 \text { to } 65 \text {, and I think the groups will have more } \\
\text { in common that way." }\end{array}$ \\
\hline \multirow{2}{*}{$\begin{array}{l}\text { Who should } \\
\text { participate }\end{array}$} & ". . . many of the people could use this most may not actually be in couples situations." \\
\hline & $\begin{array}{l}\text { "I think there is a distinction. One is not more valid than the other. But if this is specifically to } \\
\text { enrich the understanding and interaction between couples then the way the information is } \\
\text { versed and presented has to reflect that and show the ways that it strengthens what's going on } \\
\text { with a couple as it pertains to the information that you're giving versus just it being sex } \\
\text { education." }\end{array}$ \\
\hline \multicolumn{2}{|l|}{ Program incentives } \\
\hline $\begin{array}{l}\text { Motivation for } \\
\text { keeping couples in } \\
\text { the program }\end{array}$ & "I mean for the couples they always want a weekend getaway or something." \\
\hline \multicolumn{2}{|c|}{ Materials/intervention } \\
\hline \multirow{2}{*}{$\begin{array}{l}\text { Thoughts about } \\
\text { games in the manual }\end{array}$} & "I really like the idea of having the games." \\
\hline & $\begin{array}{l}\text { "I was going to say have an alternative game for that same time in the class, so based on your } \\
\text { class, especially if it's the younger group who typically are a little - can't sit as long or don't } \\
\text { have the tolerance to actually wait for somebody to get Bingo. You might get a game that's a } \\
\text { little faster moving or if you have a class and you know that your class is like that. You have an } \\
\text { option to Bingo. Maybe you can choose based on kind of your class." }\end{array}$ \\
\hline $\begin{array}{l}\text { Session } 2 \text { (Pictures } \\
\text { associated with STIs } \\
\text { and HPV) }\end{array}$ & "That's too bold"; "That's reality"; "Yeah, leave it." \\
\hline $\begin{array}{l}\text { Session } 5 \text { (Act It } \\
\text { Out) }\end{array}$ & $\begin{array}{l}\text { "Yeah, dialoging and doing the props and the - I think - we like to do miming and - so I } \\
\text { think acting it out - most people like to participate in being somebody they aren't." }\end{array}$ \\
\hline $\begin{array}{l}\text { Session } 6 \\
\text { (community } \\
\text { presentations) }\end{array}$ & $\begin{array}{l}\text { "I think that goes into the campaign, the drama presentation, the skits, the video - everything } \\
\text { that we kind of laid out in terms of having the Pastors to get on board and involve the } \\
\text { leadership. Pretty much those things, they go into that. Those are the best ways." } \\
\text { "I think we really got to push out the fun aspects. This is going to be a fun environment. You're } \\
\text { not coming here to sit here and be like bored to death. It's fun." } \\
\text { Abbreviations: STIs, sexually transmitted infections; HPV, human papilloma virus. }\end{array}$ \\
\hline
\end{tabular}

Table 3. Examples of Changes From Con Amor Aprendemos to With Love We Learn, Atlanta, Georgia, 2012 


\begin{tabular}{|c|c|c|c|}
\hline $\begin{array}{l}\text { Manual } \\
\text { Component }\end{array}$ & $\begin{array}{c}\text { Con Amor } \\
\text { Aprendemos }\end{array}$ & Comment/Reason for Adaptation & With Love We Learn \\
\hline Pictures & $\begin{array}{l}\text { See the first picture in } \\
\text { Figure } 2\end{array}$ & $\begin{array}{l}\text { The photos of an African American } \\
\text { couple relate to the African American } \\
\text { community more than the } \\
\text { Hispanic/Latino couple. }\end{array}$ & See the second picture in Figure 2 \\
\hline Sessions & $\begin{array}{l}7 \text { Sessions - } 1 \\
\text { session/week }\end{array}$ & $\begin{array}{l}\text { The participants would be taking time } \\
\text { out of their busy schedules; be mindful } \\
\text { of the session days and lengths. }\end{array}$ & $\begin{array}{l}6 \text { sessions }-2 \text { sessions/week for } 3 \\
\text { weeks }\end{array}$ \\
\hline $\begin{array}{l}\text { Titles of health } \\
\text { leaders }\end{array}$ & Promotoras & $\begin{array}{l}\text { The English translation is more suitable } \\
\text { for the African American community. }\end{array}$ & Health educators \\
\hline Games & $\begin{array}{l}\text { Games (Bingo) to } \\
\text { learn about STI's in } \\
\text { the Hispanic } \\
\text { community }\end{array}$ & $\begin{array}{l}\text { The younger crowd would like a more } \\
\text { fun and interactive game. }\end{array}$ & $\begin{array}{l}\text { With Love We Learn "Myth Buster" } \\
\text { was created to give more variety. }\end{array}$ \\
\hline Statistics & $\begin{array}{l}\text { Statistics for cervical } \\
\text { cancer among Latina } \\
\text { women }\end{array}$ & $\begin{array}{l}\text { Update the statistics for women } \\
\text { infected with cervical cancer. }\end{array}$ & $\begin{array}{l}\text { Statistics were updated with } \\
\text { relevant data on cervical cancer for } \\
\text { African American women. }\end{array}$ \\
\hline $\begin{array}{l}\text { Dialogues/role } \\
\text { playing }\end{array}$ & $\begin{array}{l}\text { Settings for dialogues } \\
\text { should be culturally } \\
\text { relevant (ie, salon } \\
\text { restaurant) }\end{array}$ & $\begin{array}{l}\text { The settings for the dialogues need to } \\
\text { be more relevant to the African } \\
\text { American community. }\end{array}$ & $\begin{array}{l}\text { Some of the scripts for the } \\
\text { dialogues were edited to make } \\
\text { them more relevant to the African } \\
\text { American community. }\end{array}$ \\
\hline $\begin{array}{l}\text { Dialogues/role } \\
\text { playing }\end{array}$ & $\begin{array}{l}\text { Conversation and role } \\
\text { playing between } \\
\text { Hispanic males }\end{array}$ & $\begin{array}{l}\text { Many black men do not like to talk, so it } \\
\text { will be important to create leading } \\
\text { questions instead of open-ended } \\
\text { questions to stimulate conversation and } \\
\text { sharing. }\end{array}$ & $\begin{array}{l}\text { The language in the dialogues } \\
\text { (particularly the one between the } \\
\text { two men) was edited in a way that } \\
\text { would make them feel more } \\
\text { comfortable discussing the topic. }\end{array}$ \\
\hline
\end{tabular}

\begin{tabular}{|c|c|}
\hline Topic & Questions \\
\hline $\begin{array}{l}\text { Program and } \\
\text { delivery }\end{array}$ & $\begin{array}{l}\text { 1. Generally couples of different ages are combined together when this program is given } \\
\text { to the community. However we have divided the couples based on } 2 \text { defined age } \\
\text { groups. The } 2 \text { age groups are } 21-29 \text { and } 30-65 \text {. Are these categories appropriate to } \\
\text { allow for open conversation? } \\
\text { 2. In addition, we have defined the program population to be individuals who are } \\
\text { married, engaged, or in long-term relationships. What is your opinion about who } \\
\text { should participate in the program? } \\
\text { 3. Thinking about your members, how would they feel about a program to promote } \\
\text { women's health and getting a pap test? } \\
\text { 4. How will your members react to a program which addresses sensitive issues such as: } \\
\quad \text { a. male and female anatomy } \\
\text { c. monogamy } \\
\text { d. condoms } \\
\text { e. different forms of sexual activities } \\
\text { f. vaccines } \\
\text { 5. What are your thoughts about using the church to deliver health messages or } \\
\text { materials? } \\
\text { 6. Would you change anything related to the delivery of the program? If so, what would } \\
\text { you change? } \\
\text { 7. What issues and challenges do you foresee in churches delivering health interventions } \\
\text { such as this one? }\end{array}$ \\
\hline
\end{tabular}


Preventing Chronic Disease | Adaptation of a Cervical Cancer Education Program for Afr... Page 9 of 9

\begin{tabular}{|c|c|}
\hline Topic & Questions \\
\hline & $\begin{array}{l}\text { 8. Do you have any advice about delivering a health program in a church setting? If yes, } \\
\text { please tell us more. }\end{array}$ \\
\hline Incentives & $\begin{array}{l}\text { 1. What would motivate your members and couples to participate in this program? } \\
\text { 2. What strategies or incentives would you recommend to recruit them into the program? } \\
\text { What about for keeping them in the program? }\end{array}$ \\
\hline Materials/curriculum & $\begin{array}{l}\text { 1. What changes would you make to the materials such as information or pictures that } \\
\text { would make the program work for your members? } \\
\text { 2. What are your thoughts about the games in the manual? What are your suggestions } \\
\text { for games to be used to reinforce the information in the sessions? } \\
\text { a. Anatomy game } \\
\text { b. STI game } \\
\text { c. Bingo: Truth and myth } \\
\text { 3. Are the symbols used in the manual understandable? } \\
\text { 4. Are the educational tools and resources easy to use (STI chart and media material)? } \\
\text { a. Chart } \\
\text { b. Female anatomy coloring sheets } \\
\text { c. Rings of knowledge } \\
\text { d. Parking Lot } \\
\text { e. Concentration game } \\
\text { f. Dialogues } \\
\text { 5. Do you think the pre- and posttests are clear and understandable for the population in } \\
\text { your church? } \\
\text { 6. Sessions } 1 \text { through } 6 \text { : were the materials understandable and clear? }\end{array}$ \\
\hline Technical assistance & $\begin{array}{l}\text { 1. We will have training on how to deliver the intervention. What other things could help } \\
\text { the faith-based leaders with conducting the program? } \\
\text { 2. If booster sessions or follow-up training are needed, what is the best way to offer } \\
\text { these trainings? }\end{array}$ \\
\hline
\end{tabular}

Abbreviation: STI, sexually transmitted infection.

The opinions expressed by authors contributing to this journal do not necessarily reflect the opinions of the U.S. Department of Health and Human Services, the Public Health Service, the Centers for Disease Control and Prevention, or the authors' affiliated institutions.

For Questions About This Article Contact pcdeditor@cdc.gov

Page last reviewed: April 24, 2014

Page last updated: April 24, 2014

Content source: National Center for Chronic Disease Prevention and Health Promotion

Centers for Disease Control and Prevention 1600 Clifton Rd. Atlanta, GA 30333, USA

800-CDC-INFO (800-232-4636) TTY: (888) 232-6348 - Contact CDC-INFO

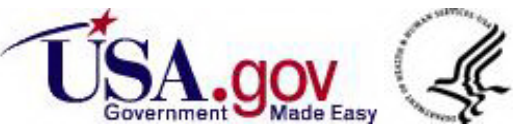

